\title{
A Bayesian Probability Model Can Simulate the Knowledge of Soybean Rust Researchers to Optimize the Application of Fungicides
}

Gregory Vinícius Conor Figueiredo, Instituto Federal do Paraná, Campus Telêmaco Borba, Paraná, Brazil

Lucas Henrique Fantin, Universidade Estadual de Londrina, Londrina, Brazil

(iD) https://orcid.org/0000-0002-5632-3007

Marcelo Giovanetti Canteri, Universidade Estadual de Londrina, Londrina, Brazil

José Carlos Ferreira da Rocha, Universidade Estadual de Ponta Grossa, Santos Andrade, Brazil

David de Souza Jaccoud Filho, Universidade Estadual de Ponta Grossa, Santos Andrade, Brazil

\section{ABSTRACT}

Asian rust is the main soybean disease in Brazil, causing up to $80 \%$ of yield reduction. The use of fungicides is the main form of control; however, due to farmer's concern with outbreaks many unnecessary applications are performed. The present study aims to verify the usefulness of a probability model to estimate the timing and the number of fungicides sprays required to control Asian soybean rust, using Bayesian networks and knowledge engineering. The model was developed through interviews with rust researchers and a literature review. The Bayesian network was constructed with the GeNIe 2.0 software. The validation process was performed by 42 farmers and 10 rust researchers, using 28 test cases. Among the 28 tested cases, generated by the system, the agreement with the model was $47.5 \%$ for the farmers and $89.3 \%$ for the rust researchers. In general, the farmers overestimate the number. The results showed that the Bayesian network has accurately represented the knowledge of the expert, and also could help the farmers to avoid the unnecessary applications.

\section{KEYWORDS}

Bayesian Networks, Brazil, Decision Support, Farmers, Fungicide Application, Glycine Max (L.) Merr, Knowledge Engineering, Phakopsora Pachyrhizi 


\section{INTRODUCTION}

Asian soybean rust (ASR), which is caused by the fungus Phakopsora pachyrhizi Syd $\&$ P. Syd, is the most devastating soybean disease in tropical and subtropical regions. The disease causes annual losses of approximately 2 billion USD in Brazil (Godoy et al., 2016). The yield losses caused by the disease are directly related to the progression and severity linked to biotic and abiotic factors such as environmental conditions, such as temperature and humidity (Melching et al., 1989; Tsukahara et al., 2008; Alves et al., 2011; Igarashi et al., 2014).

Fungicides are the main disease control strategy that have been effectively adopted by farmers. Due to the destructivity capacity of fungus, unnecessary applications are often performed, but missing applications also occur (Godoy et al., 2009). Additionally, increased fungicide applications can promote selection of resistant populations (van den Bosch et al., 2014). One method of safely and sustainably managing the aggressive potential of the disease is to use forecasting systems, which can indicate the infection risk and appropriate time for fungicide application.

In this context, several authors have proposed the development of expert systems to support decision making as well as the detection, diagnosis, and management of the disease (Alves et al., 2011; Fantin et al., 2019; Igarashi et al., 2016; Zhu et al., 2013). The expert system represents and rationalizes the knowledge of a domain to solve problems and provide information (Montazer et al., 2009), encoding the relevant knowledge in a formal model known as a knowledge base.

In the model estimating fungicide application to control Asian rust, uncertainty can arise from yet unknown processes and factors. Probability theory provides a strategy to manage uncertain knowledge, and in this context, the formalism of Bayesian networks has been employed to develop knowledge-based systems. Studies that have applied Bayesian networks include those focused on the treatment and reuse of wastewater (Carvajal et at., 2015; Beaudequin et al., 2016), modelling to understand and prognose the pathogen behaviour and the epidemiology of infectious diseases (Zhu et al., 2013; Yin et al., 2015), and genetic estimation in animals that are most susceptible to certain pathogens in livestock (Özkan et al., 2016).

The Bayesian network can be represented by a directed acyclic graph in which the nodes represent the variables of the problem and the arcs are the conditional dependency relationships between the connected nodes. Thus, $X=\left\{X \_1 \ldots X \_n\right\}$ is a set of categorical random variables, and $E$ is a set of statements indicating a binary relationship that informs the direct conditional dependence between pairs of variables. Russell and Norvig (2003) summarize the Bayesian network in a graph $G=(X, E)$, in which each element $X$ is a node in the network and each arc $\left(X_{-} i, X_{-} j\right)$ belongs to $E$. The set of parents of $\mathrm{X}$ in $\mathrm{G}$ is denoted by parents $(\mathrm{X})$.

The present study aims to verify the potential for using a probability model constructed with expert knowledge to estimate the need for fungicides and the number of applications required to control ASR using the formalism of Bayesian networks and knowledge engineering. 


\section{METHODOLOGY}

The model was constructed in the following three steps: (I) modelling to diagnose the disease, determined by relevant variables to predict an ASR epidemic; (II) adaptation of the created model into a qualitative model to estimate fungicide application; and (III) construction of the quantitative model. All of the developmental stages were performed using GeNIe version 2.0 (Druzdzel, 1999).

\section{Qualitative Model}

The qualitative model was created to formalize objectives and identify the variables and objects of the domain. The process was conducted through interviews with the expert "A". The interview was carried out after the 2013 soybean season and led to a graph of a Bayesian network for Asian rust. The variables and objects proposed by expert A were analysed by experts B, C, and D. The defined variables were adapted via an iterative process, with the insertion and removal of variables at each step, which resulted in the Bayesian network for estimating the application of fungicides to control ASR, as shown in Figure 1.

For descriptive purposes, the model can be divided into two subnetworks: subnetwork 1 concerns the first fungicide application, and subnetwork 2 concerns the additional applications. The variable of interest in subnetwork 1 refers to the first application (AI) and is directly influenced by WF, PS, PF, CC, D, and PSC (Table 1).

Based on Andrade and Andrade (2002) and Tsukahara et al. (2008), the weather forecast (WF) variable direct influences variable A1 because it forecasts the temperature and humidity which are essential requirements for the initiation and development of the disease. The same principle was used for variable PS, given that, according to Furtado et al. (2009) and Xavier et al. (2017), the phenological stage of the plant also

Figure 1. Graph of a Bayesian network (subnetwork 1 and 2) model obtained from an expert to estimate fungicide applications to soybean crops to control Asian rust

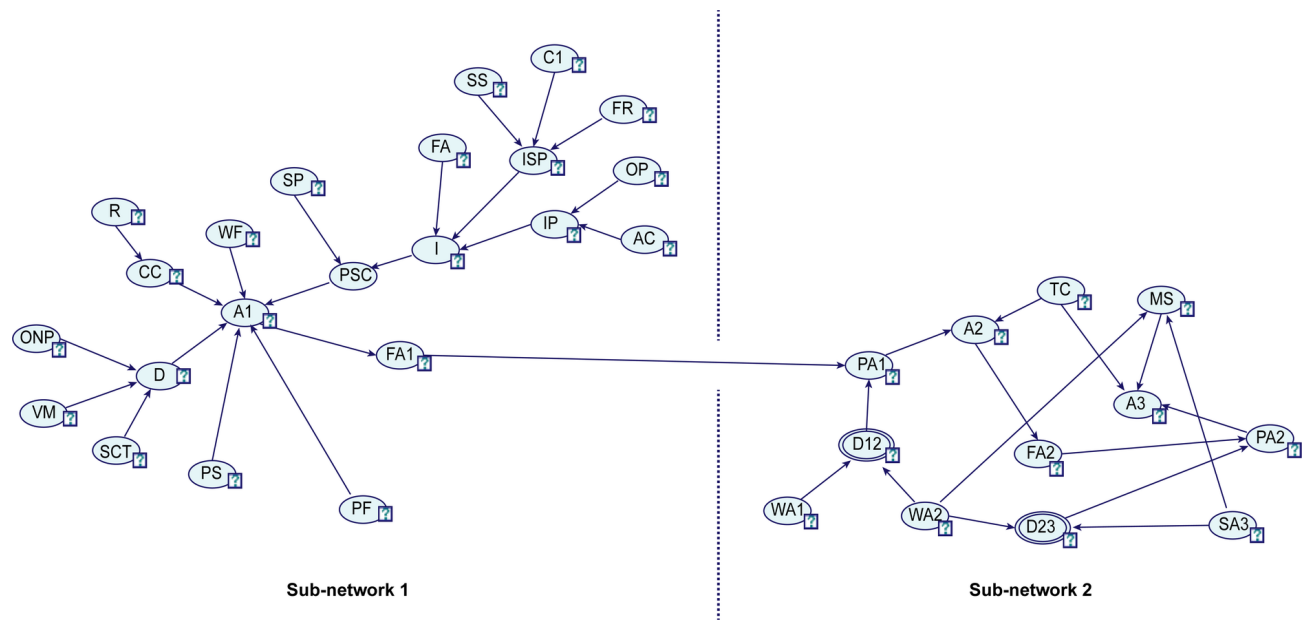


Table 1. Variables of the Bayesian model for estimating fungicide application to soybean crops to control Asian rust, subnetwork 1

\begin{tabular}{|c|c|c|}
\hline & Name & Description \\
\hline A1 & First fungicide application & Decision regarding the execution of the application \\
\hline SCT & Spore collection trap & Indicates that spores were found in the trap \\
\hline $\mathrm{R}$ & Rain & Incidence of rain in the region \\
\hline $\mathrm{AC}$ & Aerial current from west to east & Aerial current from Paraguay to Paraná \\
\hline $\mathrm{CC}$ & Climate conditions & Conditions favourable for Asian rust \\
\hline WR & Winter rain & Rain in the off-season period \\
\hline PSC & Pre-seeding conditions & Favourable conditions before the beginning of seeding \\
\hline $\mathrm{D}$ & Detection & Methods for detecting Asian rust \\
\hline PS & Phenological stage & Verifies the initial phenological states of the soybeans \\
\hline SP & Seeding period & $\begin{array}{l}\text { Verifies whether the seeding was performed during the } \\
\text { recommended period }\end{array}$ \\
\hline FA1 & Fungicide used in the first application & Chemical group of the fungicide used in the application \\
\hline FR & Frost & Incidence of frost in the off-season \\
\hline I & Inoculum & Presence of inoculum before seeding \\
\hline IP & Inoculum coming from Paraguay & Evidence of inoculum coming from Paraguay \\
\hline ISP & Inoculum in spontaneous plants & Presence of the inoculum in spontaneous plants in the off-season \\
\hline VM & $\begin{array}{l}\text { Presence of the inoculum in spontaneous } \\
\text { plants in the off-season }\end{array}$ & Most common method of identifying rust in a plantation \\
\hline ONP & Occurrence in neighbouring plantations & Evidence of Asian rust in neighbouring plantations \\
\hline OP & Occurrence in Paraguay & Evidence of inoculum in Paraguay \\
\hline $\mathrm{PF}$ & Profile of the farmer & Profile of the soybean farmer (innovative or conservative) \\
\hline WF & Weather forecast for the next five days & Forecast of favourable conditions in the next 5 days \\
\hline SS & Soybean and second crop & Soybeans in the off-season \\
\hline FA & Fallowing in the region & Presence of fallowing in the off-season period \\
\hline
\end{tabular}

directly affects infection and development of the disease; thus, it influences decision making regarding fungicide application.

Although the variables $C C, D$, and $P S C$ directly influence variable $A 1$, they are also influenced by other variables. $C C$ is influenced by the variable $R$. Thus, $R$ directly influences $C C$ and indirectly influences $A l$. The same principle applies to the variable for Asian rust detection $(D)$, which indicates whether the disease has been detected in the crop and is directly influenced by the variables $O N P, V M$, and $S C T$. The "preseeding conditions" ( $P S C$ ) variable is mainly influenced by the variables $S P$ and $I$. $P S C$ represents the elements that characterize favourable conditions the development of the disease before sowing.

Subnetwork 2 (Figure 1 and Table 2) is intended to simulate the decision of the expert " $A$ " in relation to the additional fungicide applications, that is, the applications performed because the protection period of the first application ends. 
Table 2. Variables of the Bayesian model for estimating additional fungicide applications on soybean crops to control Asian rust, subnetwork 2

\begin{tabular}{|c|c|c|}
\hline & Name & Description \\
\hline $\mathrm{A} 2$ & Second fungicide application & $\begin{array}{l}\text { Decision regarding the execution of the } \\
\text { application }\end{array}$ \\
\hline A3 & Third fungicide application & $\begin{array}{l}\text { Decision regarding the execution of the } \\
\text { application }\end{array}$ \\
\hline D12 & $\begin{array}{l}\text { Difference between the first and the } \\
\text { second application }\end{array}$ & Difference, in days, between the applications \\
\hline D23 & $\begin{array}{l}\text { Difference between the second and the } \\
\text { third application }\end{array}$ & \\
\hline MS & Maturation stage & $\begin{array}{l}\text { Verifies the final phenological states of the } \\
\text { soybeans }\end{array}$ \\
\hline FA2 & Fungicide used in the second application & $\begin{array}{l}\text { Chemical group of the fungicide used in the } \\
\text { application }\end{array}$ \\
\hline PA1 & $\begin{array}{l}\text { Residual period for the product used in the } \\
\text { first application }\end{array}$ & $\begin{array}{l}\text { Period during which the fungicide will be having } \\
\text { an effect }\end{array}$ \\
\hline PA2 & $\begin{array}{l}\text { Residual period for the product used in the } \\
\text { second application }\end{array}$ & \\
\hline WA1 & Week of first application & $\begin{array}{l}\text { Week of the cycle in which the application was } \\
\text { performed }\end{array}$ \\
\hline WA2 & Week of second application & \\
\hline WA3 & Week of third application & \\
\hline $\mathrm{TC}$ & Tolerance of the cultivar & $\begin{array}{l}\text { Indicates if the cultivar is genetically tolerant to } \\
\text { Asian rust }\end{array}$ \\
\hline
\end{tabular}

In this subnetwork, most of the variables and influences are similar to those in the subnetwork of the first application. However, in this case, the subnetwork has two special types of nodes: deterministic and noisy-MAX. Deterministic or noisy-OR is represented by situations in which the response variable is influenced bt independent variables and can assume two values (Neapolitan, 2013). The noisy-MAX enables the development of structures with more than two conditions influencing the variable response. The structure is considered the generalization of noisy-OR (Zagorecki and Drusdezel, 2013).

\section{Quantitative Model}

The quantitative model of the Bayesian network aimed to define how much one variable influences another; however, even variables that are not influenced by any other are subject to quantification of their values. The variables $W F, R, O N P, V M, S C T, P S$, $P F, S P, F A, S S, W R, F R, O P$, and $A C$ were not influenced by any other variable in the model. The a priori distributions for these variables were assumed to be uniform because the prototype was not developed for use at a specific location or on a specific 
date, meaning that the values were assumed only as a record of evidence. The variables used are shown in Table 3.

The tables of conditional probability (TCPs) for the other variables indicate the values determined by experts $\mathrm{A}, \mathrm{B}, \mathrm{C}$, and D during the interviews in which they described expectations based on their experiences. Tables $4 \mathrm{a}, 4 \mathrm{~b}$, and $4 \mathrm{c}$ show the TCPs for the variables $A 1, A 2$, and $A 3$. The other nodes developed for the networkwith the exception of $M S, D 12$, and $D 23$-were also probabilistic.

The MS node is influenced by disjunctive conditions; thus, it was inserted into the Bayesian network as noisy-MAX. The distribution was performed based on the degree to which the soybeans filled out. Until stage R6, the grain is still in formation and can be in the R5.5 stage (the last before R6) with a degree of grain fullness between $76 \%$ and 100\%. According to EMBRAPA (2013), in stage R6, the grain will be complete. The distribution of values for this node was constructed in such a manner to show the following:

$P(M S=$ untilR $6 \vee W A 2 \leq 15)=1.0$

Table 3. Variables and their respective values adopted in the Bayesian network model for estimating the application of fungicides to soybean crops to control Asian rust

\begin{tabular}{|l|l|l|l|}
\hline \multicolumn{1}{|c|}{ Abbreviation } & \multicolumn{1}{|c|}{ Aalues } & Abbreviation & \multicolumn{1}{c|}{ Values } \\
\hline A1 & no, yes & FR & a little, a lot \\
\hline A2 & no, yes & I & low, high \\
\hline A3 & no, yes & IP & absent, present \\
\hline SCT & absent, present & ISP & low, high \\
\hline R & a little, normal, a lot & VM & negative, positive \\
\hline AC & no, yes & ONP & no, yes \\
\hline CC & unfav, fav & OP & no, yes \\
\hline WR & dry, normal, rainy & PF & conservative, innovative \\
\hline PSC & unfav, fav & PA1 & $\begin{array}{l}\text { withinPeriod, } \\
\text { outsidePeriod }\end{array}$ \\
\hline D & absent, present & PA2 & $\begin{array}{l}\text { withinPeriod, } \\
\text { outsidePeriod }\end{array}$ \\
\hline D12 & $\begin{array}{l}\text { lessthan14days, between 14\&21days, more than } \\
\text { 21days }\end{array}$ & WF & $\begin{array}{l}\text { withinPeriod, } \\
\text { outsidePeriod }\end{array}$ \\
\hline D23 & $\begin{array}{l}\text { lessthan14days, between 14\&21days, more than } \\
\text { 21days }\end{array}$ & WA1 & $1 \ldots 17$ \\
\hline PS & beforeFlowers, fromFlowersOnward & WA2 & $1 \ldots 17$ \\
\hline MS & untilR6, fromR6Onward & WA3 & $1 \ldots 17$ \\
\hline SP & early, normal, late & SS & no, yes \\
\hline FA1 & triazolEstrob, carbEstrob & FC & susceptible, tolerant \\
\hline FA2 & triazolEstrob, carbEstrob & no, yes \\
\hline
\end{tabular}


Table 4. Conditional probability for the (a) first application, (b) second application, and (c) third application variables for the Bayesian network model for estimating fungicide application to soybeans to control Asian rust

\begin{tabular}{|c|c|c|c|c|c|c|c|c|c|c|c|c|c|}
\hline \multicolumn{14}{|c|}{ First Application (a) } \\
\hline D & \multicolumn{12}{|l|}{ Absent } & Present \\
\hline PS & \multirow{2}{*}{\multicolumn{2}{|c|}{ beforeflowers }} & \multicolumn{10}{|c|}{ FromfloweringOnwards } & \\
\hline PF & & & \multicolumn{2}{|c|}{ Conservative } & \multicolumn{8}{|c|}{ Inovative } & \\
\hline $\mathrm{CC}$ & & & & & \multicolumn{4}{|l|}{ Unf. } & \multicolumn{4}{|l|}{ Fav } & \\
\hline WF & & & & & \multicolumn{2}{|l|}{ Unf. } & \multicolumn{2}{|l|}{ Fav. } & \multicolumn{2}{|l|}{ Unf. } & \multicolumn{2}{|l|}{ Fav. } & \\
\hline PSC & & & & & Unf. & Fav. & Unf. & Fav. & Unf. & Fav. & Unf. & Fav. & \\
\hline No & 1 & & 0 & & 1 & 0.8 & 0.3 & 0.2 & 0.7 & 0.5 & 0.3 & 0 & 0 \\
\hline Yes & 0 & & 1 & & 0 & 0.2 & 0.7 & 0.8 & 0.3 & 0.5 & 0.7 & 1 & 1 \\
\hline \multicolumn{14}{|c|}{ Second Application (b) } \\
\hline TC & \multicolumn{4}{|c|}{ Susceptible } & & & & \multicolumn{6}{|c|}{ Tolerant } \\
\hline PA1 & \multicolumn{4}{|c|}{ WithinPeriod } & \multicolumn{3}{|c|}{ OutsidePeriod } & \multicolumn{3}{|c|}{ WhitinPeriod } & \multicolumn{3}{|c|}{ OutsidePeriod } \\
\hline No & \multicolumn{4}{|l|}{1} & \multicolumn{3}{|l|}{1} & \multicolumn{3}{|l|}{1} & \multicolumn{3}{|l|}{1} \\
\hline Yes & \multicolumn{2}{|l|}{0} & & & \multicolumn{3}{|l|}{0} & \multicolumn{3}{|l|}{0} & \multicolumn{3}{|l|}{0} \\
\hline \multicolumn{14}{|c|}{ Third Application (c) } \\
\hline TC & \multicolumn{6}{|c|}{ Susceptible } & \multicolumn{7}{|c|}{ Tolerant } \\
\hline MS & \multicolumn{3}{|l|}{ UntilR6 } & \multicolumn{3}{|c|}{ FromR6onward } & Until & & & & FromR & onward & \\
\hline PA2 & WithinP. & Outside & & WhitinP. & Out & deP. & With & & Outsid & & Whitin & & OutsideP. \\
\hline No & 1 & 1 & & 1 & 1 & & 1 & & 1 & & 1 & 1 & 1 \\
\hline Yes & 0 & 0 & & 0 & 0 & & 0 & & 0 & & 0 & c & ) \\
\hline
\end{tabular}

Fav=favourable; Unf=Unfavourable; Whithin; $\mathrm{P}=$ WhitinPeriod; Outsidep=OutsidePeriod

$P(M S=$ untilR $6 \vee W A 3 \leq 15)=1.0$

$P(M S=$ fromR6onward $\vee W A 2>15)=1.0$

and:

$P(M S=$ fromR6onward $\vee W A 3>15)=1.0$

Table 5 shows the conditional probability for the variable MS. The LEAK value represents the probability of reaching the R6 stage, even without all evidence available (Zagorecki and Druzdzel, 2004).

The nodes D12 and D23 are deterministic and do not have a TCP. Thus, the values of these nodes were determined from the difference between the weeks of fungicide application, which generates value considered to be the residual period for the product 
Table 5. Table of conditional probability (TCP) for the "maturation stage" (MS) variable for the Bayesian network model for estimating fungicide application to soybeans to control Asian rust

\begin{tabular}{|l|l|l|l|l|l|l|l|}
\hline & \multicolumn{3}{|c|}{ WA2 } & \multicolumn{3}{c|}{ WA3 } & LEAK \\
\hline & $1 \ldots 15$ & 16 & 17 & $1 \ldots 15$ & 16 & 17 & \\
\hline untilR6 & 1 & 0 & 0 & 1 & 0 & 0 & 0.7 \\
\hline fromR6onward & 0 & 1 & 1 & 0 & 1 & 1 & 0.3 \\
\hline
\end{tabular}

WA2: weeks after the second application

WA3: weeks after the third application

LEAK: the value that represents the probability of reaching the $\mathrm{R} 6$ stage, even without the presence of all of the evidence.

untilR6: the plants in the phenological stage by R6 (EMBRAPA, 2013).

fromR6Onward: the plants in the phenological stage in or after R6 (EMBRAPA, 2013).

applied. The algorithms with the logic for the representation of these values are shown in Figure 2.

\section{Validation}

The Bayesian network for defining fungicide application to control Asian rust was tested and validated for the state of Paraná in the southern region of Brazil using the 2013 knowledge of fungicide application. The Bayesian model test was performed with 42 farmers and 10 ASR researchers. The test was composed of test cases, which represent the conditions or situations (i.e., rain, detection of Asian rust) used for decision making regarding fungicide application.

The performance of test cases occurred in three steps. For the first step, the test cases used were proposed by expert A and were also generated by GeNIe 2.0 software. The test cases of the first step were conducted by experts B, C, and D. In the second step, the number of test cases increased according to situations proposed by experts B, C, and D. Based on the test cases proposed in the first and second steps, the software generated different combinations of test cases. The test case was conducted by 10 rust researchers and 42 farmers.

Figure 2. Algorithm with the logic for the representation of the values used in the Bayesian network model for estimating fungicide application to soybean crops to control Asian rust

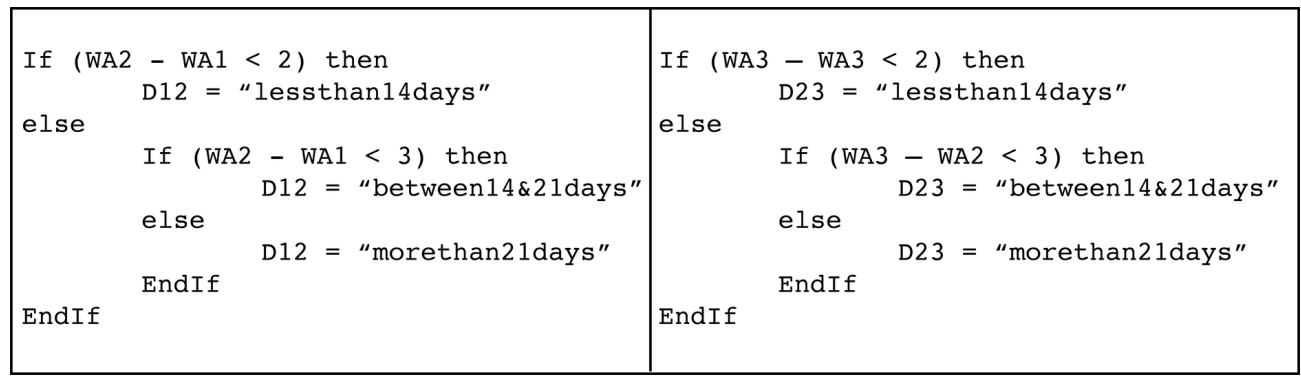




\section{RESULTS AND DISCUSSION}

\section{First Stage}

The test cases for validation expressed situations that had previously been faced by expert A, who was responsible for constructing the model, and additional situations faced by experts B, C and D. The information on such cases was included in the network that was implemented in GeNIe 2.0 software. The result of each proposed case was assumed by the model as a hypothesis of maximum posterior probability for the variables of interest- $\mathrm{A} 1, \mathrm{~A} 2$, and $\mathrm{A} 3$.

As expected, experts B, C, and D approved the results. Using an example of expert B proposing a test case to decide on the first fungicide application, the following set of evidence was informed:

1. R: normal; (see Table 3);

2. IP: present.

Given the evidence provided, the result displayed by the system for variable A1 was yes with a probability of 0.878 and no with a probability of 0.122 , as shown in Figure 3.

Assuming the Bayesian decision rule of maximum posterior probability, the decision reported by the system indicated the performance of the first fungicide application, in accordance with the choice of the expert. The results can be explained by the combination of the evidence of rain (Del Ponte et al., 2006; Tsukahara, et al., 2008), leaf moisture (Igarashi et al., 2014), and inoculum (Minchio et al., 2016).

Figure 3. Probabilities for A1 variable (first application of fungicide), given the evidence for $R$ (rain) and IP (inoculum coming from Paraguay), for the Bayesian network model for estimating the fungicide application to soybean crops to control Asian rust

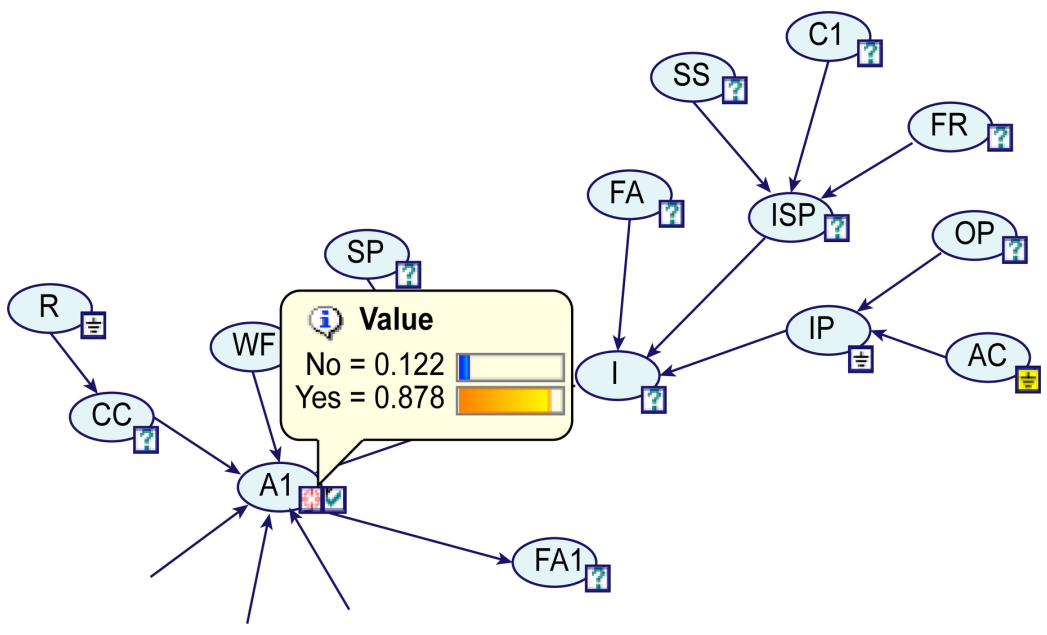




\section{Second Stage}

Subsequently, in the second stage of testing, experts B, C, and D proposed another eight test cases with different combinations of evidence. The responses informed by the system for the variables of interest $(A 1, A 2$, or $A 3)$ agreed with the decisions of experts B, C, and D and the proposed cases. According to Tsukahara et al. (2008), effective disease control is mainly related to the timing of application. In addition to promoting disease effective control, performing applications at the correct time and in the correct number also contributes to issues such as reducing the appearance of fungicide-resistant populations (Godoy, 2012; van den Bosch et al., 2014), which in turn reduces the number of applications and environmental damage. Problems of reduced sensitivity to the fungicides used in disease control have been observed by Xavier et al. (2015), Reis et al. (2015), Klosowski et al. (2016), Schmitz et al. (2014), and Simões et al. (2018), who noted the need to apply fungicide with caution.

\section{Third Stage}

In the third stage of testing, the software generated different combinations of input variables. The input and output variables were selected, and the system was responsible for determining different combinations of values. Each test case was shown to the 10 rust researchers and 42 farmers to verify whether their answers were consistent with those generated by the system.

The validation script of the test cases was as follows:

- The general description of the model to each of the rust researchers;

- The exhibition of model implementation in GeNIe 2;

- The performance of tests for decision making regarding each of the possible applications;

- The presentation of the TCPs for each variable, when of interest to the expert.

The outputs generated for each test case-which had the variables $A 1, A 2$, and $A 3$ as targets-were considered by the rust researchers. In total, GeNIe generated 28 test cases. The rust researchers' decisions showed the agreement of $89.3 \%$ with the model in relation to their expectations. However, the farmers' decisions showed $47.5 \%$ agreement.

The low agreement of farmers can be attributed to the limited information available to them. Usually, the application decision by farmers is based on the date and does not consider the parameters and favourable variables for disease occurrence. Thus, this practice can result in unnecessary applications. The present study demonstrated that using the formalism of Bayesian networks to construct an expert system is effective for predicting the need for fungicides and the number of applications required to control ASR. Thus, instead of setting a date and number of fungicide applications (which is often overestimated), it was possible to make accurate decisions about the timing and the number of applications to control ASR with the model. The same result was obtained by Carmona et al. (2015) in a study that developed a scoring system to aid 
the applications to control late season soybean diseases. This possibility indicated the potential for reducing environmental damage caused by the excessive use of fungicides as well as improving economic factors and sustainability for producers due to the reduction in unnecessary applications.

The interviews conducted with experts A, B, C, and D enabled knowledge engineering, which culminated in the construction of a validated formal model. The tests conducted showed that the model accurately simulated the need for fungicide applications. The knowledge engineering used in the model accurately represented the experts' thinking in relation to fungicide applications to control ASR in the state of Paraná. However, some variables have been changing during the seasons resulting less agreement with the model. Thus, frequent updates to incorporate more knowledge variables such as "nutritional balance", as noted by Gaspar et al. (2015), the "maturation group of the soybean cultivar" which indicates the time at which the crop will be in the field (Moreira et al., 2015), and "fungicide resistance" (Klosowski et al., 2016; Schmitz et al., 2014; Simões et al., 2018; Xavier et al., 2015) which influences the chemical group used and time between applications (Jørgensen et al., 2017; van den Bosch et al., 2014) could increase the accuracy of fungicide application requirement simulations.

\section{CONCLUSION}

Based on what has been stated, it can be concluded that the Bayesian network system simulates expert knowledge to assist in decision making regarding the need for fungicide applications. Considering that the number of fungicide applications is generally overestimated, the system has potential to reduce environmental damage caused by the excessive use of fungicides and to generate savings for producers due reduced unnecessary applications.

\section{CONFLICT OF INTEREST}

The authors have no conflicts of interest to declare.

\section{ACKNOWLEDGMENT}

This work was supported by the CNPq "National Council for Scientific and Technological Development" [grant numbers 486497-2013-5]. 


\section{REFERENCES}

Alves, M., Pozza, E. A., Costa, J. C. B., Gonsaga de Carvalho, L., \& Alves, L. S. (2011). Adaptive neuro-fuzzy inference systems for epidemiological analysis of soybean rust. Environmental Modelling \& Software, 26(9), 1089-1096. doi:10.1016/j. envsoft.2011.03.008

Andrade, P. J. M., \& Andrade, D. F. A. (2002). Ferrugem Asiática: Uma Ameaça à Sojicultura Brasileira. Circular Técnica, 11.

Beaudequin, D., Harden, F., Roiko, A., \& Mengersen, K. (2016). Utility of Bayesian networks in QMRA-based evaluation of risk reduction options for recycled water. The Science of the Total Environment, 541, 1393-1409. doi:10.1016/j.scitotenv.2015.10.030 PMID:26479913

Carmona, M., Sautua, F., Perelman, S., Gally, M., \& Reis, E. M. (2015). Development and validation of a fungicide scoring system for management of late season soybean diseases in Argentina. Crop Protection, 70, 83-91. doi:10.1016/j.cropro.2015.01.019

Carvajal, G., Roser, D. J., Sisson, S. A., Keegan, A., \& Khan, S. J. (2015). Modelling pathogen $\log 10$ reduction values achieved by activated sludge treatment using naïve and semi naïve Bayes network models. Water Research, 85, 304-315. doi:10.1016/j. watres.2015.08.035 PMID:26342914

Del Ponte, E. M., Godoy, C. V., Canteri, M. G., Reis, E. M., \& Yang, X. B. (2006). Models and applications for risk assessment and prediction of Asian soybean rust epidemics. Fitopatologia Brasileira, 31(6), 533-544. doi:10.1590/S010041582006000600001

Druzdzel, M. J. (1999). GeNie: a development environment for graphical decisionanalytic models, In: Proceedings of the AMIA Symposiu (pp. 6-10). Washington, D.C.: American Medical Informatics Association.

Embrapa Soja. (2013). Tecnologias de produção de soja-Região Central do Brasil. Londrina: Embrapa Soja.

Fantin, L. H., de Souza Madureira Felício, A. L., Braga, K., Gaeta, G. M., de Franca, J. A., \& Canteri, M. G. (2019). Spectral characterization and quantification of Phakopsora pachyrhizi urediniospores by Fourier transformed infrared with attenuated total reflectance. European Journal of Plant Pathology. doi:10.1007/s10658-019-01735-w

Furtado, G. Q., Alves, S. A. M., Carneiro, L. C., Godoy, C. V., \& Massola Júnior, N. S. (2009). Influência do estádio fenológico e da idade dos trifólios de soja na infecção de Phakopsora pachyrhizi. Tropical Plant Pathology, 34(2), 118-122. doi:10.1590/ S1982-56762009000200007 
Gaspar, G.G., Takahashi, H.W., \& Canteri, M.G., Almeida, C.V.de, Fioretto, R.A., Andrade, B.L.G., \& Fantin, L.H. (2015). Balance among calcium, magnesium and potassium levels affecting Asian Soybean Rust severity. Agronomy Science and Biotechnology, 1, 39-44.

Godoy, C. V. (2012). Risk and management of fungicide resistance in the Asian soybean rust fungus Phakopsora pachyrhizi. In T. S. Thind (Ed.), Fungicide Resistance in Crop Protection: Risk and Management (pp. 87-95). Wallingford: CAB International. doi:10.1079/9781845939052.0087

Godoy, C.V., Flausino, A.M., Santos, L.C.M., \& Del Ponte, E.M. (2009). Eficiência do controle da ferrugem asiática da soja em função do momento de aplicação sob condições de epidemia em Londrina, PR. Tropical Plant Pathology, 34, 56-61.

Godoy, C. V., Seixas, C. D. S., Soares, R. M., Marcelino-Guimarães, F. C., Meyer, M. C., \& Costamilan, L. M. (2016). Asian soybean rust in Brazil: Past, present, and future. Pesquisa Agropecuária Brasileira, 51(5), 407-421. doi:10.1590/S0100204X2016000500002

Igarashi, W.T., Aguiar e Silva, M.A., de Franca, J.A., Igarashi, S., \& Abi Saab, O.J.G. (2014). Duração e porcentagem de molhamento foliar determinados pelo espaçamento entrelinhas, e influência sobre a ferrugem asiática da soja. Summa Phytopathologica, 40, 123-127. doi:10.1590/0100-5405/1969

Igarashi, W.T., Franca, J.A.de., Aguiar e Silva, M.A., Igarashi, S., \& Abi Saab, O.J.G. (2016) Application of prediction models of Asian soybean rust in two crop seasons, in Londrina, PR. Semina: Ciências Agrárias, 37, 2881-2890. doi:10.5433/1679$0359.2016 \mathrm{v} 37 \mathrm{n} 5 \mathrm{p} 2881$

Jørgensen, L.N., Van Den Bosch, F., Oliver, R.P., Heick, T.M., \& Paveley, N. (2017). Targeting Fungicide Inputs According to Need. Annu. Rev. Phytopathol., 55, 8.1-8.23. doi:10.1146/annurev-phyto-080516

Klosowski, A. C., May De Mio, L. L., Miessner, S., Rodrigues, R., \& Stammler, G. (2016). Detection of the F129L mutation in the cytochrome b gene in Phakopsora pachyrhizi. Pest Management Science, 72(6), 1211-1215. doi:10.1002/ps.4099 PMID:26296393

Melching, J. S., Dowler, W. M., Koogle, D. L., \& Royer, M. H. (1989). Effects of duration, frequency, and temperature of leaf wetness periods on soybean rust. Plant Disease, 73(2), 117-122. doi:10.1094/PD-73-0117

Minchio, C. A., Canteri, M. G., Fantin, L. H., \& Augusto e Silva, M. A. (2016). Epidemias de ferrugem asiática no Rio Grande do Sul explicadas pelo fenômeno ENOS e pela incidência da doença na entressafra. Summa Phytopathologica, 42(4), 321-326. doi:10.1590/0100-5405/2219 
Montazer, G. A., Saremi, H. Q., \& Ramezani, M. (2009). Design a new mixed expert decision aiding system using fuzzy electre III method for vendor selection. Expert Systems with Applications, 36(8), 10837-10847. doi:10.1016/j.eswa.2009.01.019

Moreira, E. N., Vale, F. X. R., Paul, P. A., Rodrigues, F. A., \& Jesus, W. C. Junior. (2015). Temporal dynamics of soybean rust associated with leaf area index in soybean of different maturity groups. Plant Disease, 99(9), 1216-1226. doi:10.1094/PDIS10-14-1029-RE PMID:30695930

Neapolitan, R. E. (2003). Learning Bayesian Networks. Chicago: Prentice Hall.

Özkan, Ş., Vitali, A., Lacetera, N., Amon, B., Bannink, A., Bartley, D. J., \& Kipling, R. P. et al. (2016). Challenges and priorities for modelling livestock health and pathogens in the context of climate change. Environmental Research, 151, 130-144. doi:10.1016/j.envres.2016.07.033 PMID:27475053

Reis, E. M., Deuner, E., \& Zanatta, M. (2015). Sensibilidade de Phakopsora pachyrhizi a fungicidas triazóis e estrobilurina in vivo. Summa Phytopathologica, 41(1), 21-24. doi:10.1590/0100-5405/1975

Russell, S., \& Norvig, P. (2003). Artificial intelligence: a modern approach. Englewood Cliffs: Prentice Hall.

Schmitz, H. K., Medeiros, C. A., Craig, I. R., \& Stammler, G. (2014). Sensitivity of Phakopsora pachyrhizi towards quinone-outside-inhibitors and demethylationinhibitors, and corresponding resistance mechanisms. Pest Management Science, 70(3), 378-388. doi:10.1002/ps.3562 PMID:23589453

Simões, K., Hawlik, A., Rehfus, A., Gava, F., \& Stammler, G. (2018). First detection of a SDH variant with reduced SDHI sensitivity in Phakopsora pachyrhizi. Journal of Plant Diseases and Protection, 125(1), 21-26. doi:10.1007/s41348-017-0117-5

Tsukahara, R. Y., Hikishima, M., \& Canteri, M. G. (2008). Relationship between climate and the progress of the Asian soybean rust (Phakopsora pachyrhizi) in two micro-regions of Paraná state. Semina. Ciências Agrárias, Londrina, 29, 47-52. doi:10.5433/1679-0359.2008v29n1p47

van den Bosch, F., Oliver, R., van den Berg, F., \& Paveley, N. (2014). Governing principles can guide fungicide-resistance management tactics- supplemental material. Annual Review of Phytopathology, 52(1), 175-195. doi:10.1146/annurevphyto-102313-050158 PMID:24848413

Xavier, S. A., Koga, L. J., Cristina, D., Barros, M., Canteri, M. G., Lopes, D. O. N., \& Godoy, C. V. (2015). Sensitivity variation of Phakopsora pachyrhizi populations to demethylation inhibitor fungicides in Brazil. Summa Phytopathologica, 41, 191-196. doi:10.1590/0100-5405/2068 
Xavier, S. A., Martins, D. C., Fantin, L. H., \& Canteri, M. G. (2017). Older leaf tissues in younger plants are more susceptible to soybean rust. Acta Scientiarum. Agronomy, 39(1), 17-24. doi:10.4025/actasciagron.v39i1.30638

Yin, W., Kissinger, J. C., Moreno, A., Galinski, M. R., \& Styczynski, M. P. (2015). From genome-scale data to models of infectious disease: A Bayesian network-based strategy to drive model development. Mathematical Biosciences, 270, 156-168. doi:10.1016/j.mbs.2015.06.006 PMID:26093035

Zagorecki, A., \& Druzdzel, M. J. (2004). An empirical study of probability elicitation under noisy-OR assumption, In V. Barr, \& Z. Markov (Eds.), Proceedings of the sEventtenth International Florida Artifical Intelligence Research Society Conference (FLAIRS) (pp. 880-885). Menlo Park, CA: AAAI Press.

Zagorecki, A., \& Druzdzel, M. J. (2013). Knowledge Engineering for Bayesian Networks: How Common Are Noisy-MAX Distributions in Practice? IEEE Transactions on Systems, Man, and Cybernetics. Systems, 43(1), 186-195. doi:10.1109/ TSMCA.2012.2189880

Zhu, Y., Liu, D., Chen, G., Jia, H., \& Yu, H. (2013). Mathematical modeling for active and dynamic diagnosis of crop diseases based on Bayesian networks and incremental learning. Mathematical and Computer Modelling, 58(3-4), 514-523. doi:10.1016/j. mcm.2011.10.072

Gregory Vinícius Conor Figueiredo, Computing Engineer and Master by Universidade Estadual de Ponta Grossa, Brazil. Researcher in Artificial Intelligence. Works in Instituto Federal do Paraná, Brazil.

Lucas Henrique Fantin, Agronomist and Master by Universidade Estadual de Londrina, Brazil. Research areas includes plant disease epidemiology and meta-analysis.

Marcelo Giovanetti Canteri, Professor, researcher, plant pathology, epidemiology, simulation model, meta analysis. 